Review

\title{
Anaerobes and Bacterial Vaginosis in Pregnancy: Virulence Factors Contributing to Vaginal Colonisation
}

\author{
Charlene W. J. Africa $^{\dagger} *$, Janske Nel ${ }^{\dagger}$ and Megan Stemmet ${ }^{\dagger}$ \\ Department of Medical Biosciences, University of the Western Cape, Private Bag X17, Bellville 7535, \\ Cape Town, South Africa; E-Mails: 2917239@uwc.ac.za (J.N.); megcstem@gmail.com (M.S.) \\ $\dagger$ These authors contributed equally to this work. \\ * Author to whom correspondence should be addressed; E-Mail: cafrica@uwc.ac.za; \\ Tel.: +27-21-959-2341; Fax: +27-21-959-3125.
}

Received: 15 May 2014; in revised form: 25 June 2014 / Accepted: 30 June 2014 /

Published: 10 July 2014

\begin{abstract}
The aetiology and pathogenesis of bacterial vaginosis (BV) is unclear but it appears to be associated with factors that disrupt the normal acidity of the vagina thus altering the equilibrium between the normal vaginal microbiota. BV has serious implications for female morbidity, including reports of pelvic inflammatory disease, adverse pregnancy outcomes, increased susceptibility to sexually transmitted infections and infertility. This paper reviewed new available information regarding possible factors contributing to the establishment of the BV vaginal biofilm, examined the proposed role of anaerobic microbial species recently detected by new culture-independent methods and discusses developments related to the effects of $\mathrm{BV}$ on human pregnancy. The literature search included Pubmed (NLM), LISTA (EBSCO), and Web of Science. Because of the complexity and diversity of population groups, diagnosis and methodology used, no meta-analysis was performed. Several anaerobic microbial species previously missed in the laboratory diagnosis of BV have been revealed while taking cognisance of newly proposed theories of infection, thereby improving our understanding and knowledge of the complex aetiology and pathogenesis of $\mathrm{BV}$ and its perceived role in adverse pregnancy outcomes.
\end{abstract}

Keywords: pregnancy outcomes; bacterial vaginosis; female morbidity; microbial ecology 


\section{Introduction}

Preterm birth (PTB) is the leading cause of neonatal morbidity and mortality world-wide, yet, the underlying causes remain largely unknown, with increased incidence reported due to intrauterine infections [1,2]. Bacterial vaginosis (BV) is a common reproductive tract infection amongst women of reproductive age [3] and has been implicated as a risk factor for adverse pregnancy outcomes such as preterm birth, recurrent abortions, post-abortal sepsis, early miscarriages and still births [2,4-7]. Infections leading to preterm birth and other complications of pregnancy may extend beyond delivery and create serious and sometimes life-threatening consequences for the neonate [8]. However, many infections are subclinical [9] and so our knowledge of the role played by BV in PTB remains limited and inconclusive.

Previously considered to be an infection initiated by the overgrowth of Gardnerella vaginalis with a concomitant loss of $\mathrm{H}_{2} \mathrm{O}_{2}$-producing lactobacilli, new evidence points to $\mathrm{BV}$ as being a polymicrobial condition, involving synergistic mechanisms between vaginal colonisers, many of which are anaerobic bacteria. Confirmation of this theory is found in the resistance to metronidazole of many BV infections, and the finding that the volatile fatty acids responsible for the "whiff test" are products of the metabolic activity of a host of anaerobes other than G. vaginalis [10]. Although not classified as a sexually transmitted infection (STI) per se, the risk for sexual transmission of certain BV-associated bacteria has been reported to increase in lesbian and heterosexual women with multiple sexual partners [11-13].

\section{Methodology}

Citation databases included Sciencedirect, PubMed, LISTA (EBSCO), and Web of Science, using the terms "bacterial vaginosis", "vaginitis", "vaginal discharge", "aetiology of vaginosis", "anaerobes in vaginosis", "preterm birth and vaginosis", "preterm delivery and asymptomatic infections", "pathogenesis of bacterial vaginosis", "virulence factors of vaginal anaerobes", "diagnosis of vaginosis" and "vaginal microbial ecology". All titles and available abstracts were screened and where relevant, full texts retrieved. In addition, reference lists of retrieved papers were examined for similar papers which could be relevant. More than 700 papers were retrieved in the initial search but only 161 papers pertaining to specific BV-associated anaerobes in pregnancy and published between the years 2000 and 2014 were included, except for a few specific earlier papers on which diagnostic methods were based. Data regarding bacteria detected, method of detection, type of study (case/control or cohort) virulence mechanisms and implication in adverse pregnancy outcomes were collected and summarised. While not claiming to be all-inclusive, an attempt was made to include the viewpoints and research outcomes which contributed new and pertinent data. Overt differences in diagnosis, proposed aetiology, sampling, detection methods, population groups and periods of gestation complicated a meta-analysis. 


\section{Results and Discussion}

\subsection{Transition from the Lactobacillus-Associated to the BV-Associated Vaginal Biofilm}

The vaginal ecosystem is established over a number of years. The dynamic environment of the vagina is influenced by factors such as hormonal fluctuations, menstruation, douching, hygiene, pregnancy, breastfeeding and sexual practices [14-27]. Skin commensals and microbiota normally inhabiting the bowel are the original colonisers of the young, healthy female vagina. Aerobic lactobacilli persist in the vagina for weeks after birth while the vaginal $\mathrm{pH}$ remains acidic. The $\mathrm{pH}$ of the vagina converts to neutral during early childhood, remaining so until puberty. A plethora of different microbial species co-exist in this vaginal ecosystem, $70 \%-90 \%$ of which are lactobacilli. During puberty and menarche, dramatic hormonal and physical changes occur in the vaginal environment favouring the colonisation of lactobacilli [26]. Although identified in both BV-positive and BV-negative women, $\mathrm{H}_{2} \mathrm{O}$ producing lactobacilli numbers are reported to be significantly increased in BV-negative females [28]. Their population dominance is considered to be beneficial in maintaining the health of the female, through their production of hydroxyl radicals, lactic acid, bacteriocins, hydrogen peroxide and probiotics [5]. After menopause, or when the vaginal lactobacilli are depressed or removed, hydrogen peroxide is no longer produced and the $\mathrm{pH}$ of the environment increases, thus facilitating the establishment of BV-associated microbial communities in the vaginal biofilm [23,29]. However, not all healthy females have vaginal microbiota dominated by lactobacilli [5], and other lactic acid producers such as Atopobium vaginae, Leptotrichia and Megasphaera have also been suggested to assist in maintaining the acidity of the vagina, [30,31]. With BV considered a non-specific (predominantly anaerobic) polymicrobial infection and the identities of many of the vaginal microflora remaining elusive [32], determining the health of the vaginal ecosystem appears to be subjective.

Two species of lactobacilli have frequently been found to colonise the healthy vagina, namely, Lactobacillus gasseri and Lactobacillus crispatus both members of the Lactobacillus acidophilus complex [33,34]. While L. crispatus and L. jensenii have a better ability to adhere to vaginal cells [35], in vitro studies have reported that acid and hydrogen peroxide production by L. acidophilus and L. casei are able to inhibit the growth of BV-associated microbes such as Gardnerella vaginalis, Mobiluncus, Bacteroides and species of anaerobic cocci, while decreased production of bacteriocins and hydrogen-peroxide by lactobacilli enhances the growth of G. vaginalis, Prevotella bivia, Mobiluncus, Peptococcus species and Peptostreptococcus anaerobius by the production of ammonia, acetic, succinic acids and amino acids respectively [36].

Lactobacillus iners has been recommended as a marker of the imbalance of the vaginal microflora leading to BV $[33,37,38]$ and its presence correlated with colonisation of other BV-associated bacteria such as Megasphaera, Leptotrichia and Eggerthella [39]. Thus the significance of the relative ratio of Lactobacillus iners, Atopobium vaginae and other anaerobes in BV provides substantial information for its diagnosis [38]. L. gassei and L. crispatus, have been associated with health, while a negative correlation has been reported between L. gasseri and L. iners; L. gasseri and Atopobium, Prevotella and G. vaginalis all of which are associated with BV [37,39-41]. L. iners is dominant after treatment for BV, and has been reported together with L. crispatus in women without BV [34] 
suggesting that $L$. iners may be an opportunistic pathogen whose prevalence and pathogenic potential is enhanced by L. gassei, an assumed later coloniser than L. crispatus.

Several mechanisms have been proposed for the establishment of the BV biofilm, namely, stress, sexual practices, microbial synergism (one organism inducing the ideal growing environment for another) or antagonism (inhibition or killing of one organism by another). Because of the polymicrobial nature of infection, growing resistance to metronidazole and other antimicrobial treatments have been reported [42]. The outcome of any infection is usually determined by the initial response of the host to invasion by an infective agent, followed by chemotaxis (the migration of polymorphonuclear neutrophils (PMNs) towards the locus of infection). This initial response to the recognition of chemotactic factors results in phagocytosis. In an effort to fully understand BV, clinicians made a distinction between vaginitis and vaginosis by defining bacterial vaginitis as an infection of the vagina associated with inflammation of the vulva, while vaginosis was defined as the degradation of the normal flora of the vagina in the absence of an associated inflammatory response [43]. The inhibition of PMN chemotaxis by virulence factors expressed by certain of the BV-associated organisms, may explain the absence of inflammation.

In order to be implicated in the aetiology of BV, a specific bacterium should demonstrate an increase in $\mathrm{BV}$ and be reduced or eliminated in the healthy vagina. BV has been attributed to an imbalance of the normal vaginal microbiota with many of the anaerobic bacteria detected in BV showing great pathogenic potential either individually or as a consortium. Symbiotic relationships appear to play an important role in the pathogenesis of BV, thereby implicating several species in its aetiology. They are examined below in the light of their effect on host defences, provision of essential nutrients for growth and survival, alteration of the environment and expression of virulence factors.

\subsection{Anaerobes Implicated in the Aetiology of $B V$}

Gardnerella vaginalis has for a long time been seen as one of the most important candidate bacteria in BV [27,44-46], with its numbers being inversely proportionate to lactobacilli in health and disease $[17,18]$. However, recognising only Gardnerella vaginalis as the overt pathogen in BV would be inaccurate, especially as G. vaginalis has shown a high sensitivity (100\%) but low specificity (49\%) for BV by also being detected in the absence of BV [14,16,28,47]. Synergy between G. vaginalis and Atopobium vaginae has been proposed as they are often detected together in BV [32,48-52] and only rarely has A. vaginae been detected in the absence of $G$. vaginalis [53] or in health [54,55]. A. vaginae was first implicated in $\mathrm{BV}$ in 2004, since then several studies have emerged associating this anaerobe with $>80 \%$ of BV cases [54,56-61]. Furthermore, a specific consortium including A. vaginae, and Leptotrichia was found to enhance the pathogenic potential of Megasphaera in BV [62], suggesting a role for A. vaginae in the aetiology of BV. Megasphaera has a symbiotic existence in the vaginal biofilm [63] and appears to be sexually transmitted, being strongly associated with women who have sex with women and with heterosexual women reporting an increased number of sexual partners [15,25].

Taxonomically unidentified bacteria designated BVAB (bacterial vaginosis associated bacteria) have morphologic features distinctly different from Atopobium, Mobiluncus, or Gardnerella and have been observed microscopically in patients with BV, attached to vaginal epithelial cells typical of the 
clue cells that characterise BV [47,64]. BVAB have been reported in HIV-positive women with BV [65] and are considered to be acquired from external reservoirs such as the anus [66]. Also associated with BV infection in HIV-positive women are M. hominis and a combination of Bacteroides, Prevotella, Leptotrichia, Atopobium and Gardnerella [49,67-72] known to attract CD4 cells to the mucosa, with a concomitant reduction in lactobacilli [67]. Among the Gram-positive anaerobic cocci known to colonise the vagina are Peptococcus, Peptostreptococcus, Peptoniphilus and Anaerococcus. However, Gram-positive anaerobic cocci have not received the attention they deserve in studies of the vaginal biofilm despite their perceived pathogenic potential and their production of metabolic end products which favour the growth of other BV-associated microbes such as Megasphaera [63]. Furthermore, an association between endometritis and BV-associated anaerobic Gram-positive cocci has been established [73], confirming their role in reproductive morbidity.

Leptotrichia amnionii and Sneathia sanguinegens (previously Leptotrichia sanguinegens) are known colonisers of the oral cavity and like other oral anaerobes implicated in the aetiology of periodontal disease such as Tannerella forsythia, Treponema denticola, Prevotella intermedia, Aggrigatibacter actinomycetemcomitans (Aa) and Porphyromonas gingivalis, have also been associated with BV [74]. Their presence in the vagina may be due to translocation during oral-gential sexual practices since they are rarely found in sexually unexposed women [15]. Known to co-colonise with G. vaginalis and other anaerobes such as Prevotella in cases of BV [49,58], L. amnionii and $S$. sanguinegens although significantly increased in women with cervical cancer, show no correlation with human papillomavirus which has been implicated in the aetiology of cervical cancer and their detection in healthy women suggests that their pathogenicity may be opportunistic [75].

\subsection{Diagnosis of Bacterial Vaginosis}

Diagnosis of BV includes clinical examination and microscopy [76,77], using Amsel criteria and Nugent scoring [78,79]. BV is characterised by a discharge (often white or yellow) with a fishy odour following the addition of $10 \%$ potassium hydroxide to the vaginal fluid, vaginal $\mathrm{pH}>4.5$ and the microscopic scoring of bacterial morphotypes along with the presence of "clue cells", vaginal epithelial cells with boarders coated with bacteria [80]. It may also be asymptomatic [9,26] which explains why it is often misdiagnosed [30]. It may be differentiated from aerobic vaginitis, which is characterised by the absence of succinate, increased sialidase activity and a host response resulting in the increased production of cytokines such as interleukin-1, -6 and $-8[43,81]$.

Laboratory-based diagnostic methods for BV include culture and anaerobic metabolic activity analysis such as the assessment of the production of short-chain volatile and non-volatile fatty acids as end products of anaerobic metabolism, and the production of specific enzymes, [82-86]. Detection of fatty acids in vaginal fluid [87-89] can differentiate between health (major lactic acid) and BV (major succinic and acetic acids) as well as monitor the effects of treatment for BV. Culture-based and molecular approaches have identified several anaerobic species in BV [18,28,39,40,48,53,90,91] with molecular methods having overcome many of the problems associated with culture and revealing species not previously reported. This has indeed awakened our awareness of the complexity of the microbial biofilm of BV (Table 1) as well as the risk and treatment of ascending subclinical infections [92]. Of the many bacteria implicated in the aetiology of BV, Leptotrichia amnionii and 
Eggerthella species are the only two species found to correlate with all of the Amsel criteria used for the diagnosis of BV [34] and in cases where no discharge is present, improved grading of bacterial morphotypes in a wet mount or Gram stain of vaginal fluid has been recommended as an alternative to Amsel criteria for the diagnosis of BV [93].

Table 1. Anaerobic microbial consortia most frequently associated with bacterial vaginosis and preterm birth.

\begin{tabular}{|c|c|c|c|c|c|c|c|c|c|c|c|c|c|c|c|}
\hline \multirow{2}{*}{ Reference } & \multicolumn{5}{|c|}{ Gram-negative Anaerobes } & \multicolumn{10}{|c|}{ Gram-positive Anaerobes } \\
\hline & $\mathbf{L a}$ & Ss & Por & Pr & Di & Av & Gv & Mob & $\mathbf{L i}$ & BVAB & Egg & Meg & Anaer & Ps & Pep \\
\hline$[9]$ & $\mathrm{x}$ & & & $\mathrm{X}$ & $\mathrm{x}$ & $\mathrm{x}$ & $\mathrm{x}$ & & & & $\mathrm{x}$ & & & & \\
\hline$[10]$ & $\mathrm{x}$ & $\mathrm{x}$ & & & & $\mathrm{x}$ & & & & & $\mathrm{x}$ & $\mathrm{x}$ & & & \\
\hline [15] & & & & & & $\mathrm{x}$ & $\mathrm{x}$ & & & $\mathrm{x}$ & & $\mathrm{x}$ & & & \\
\hline [18] & & & & $\mathrm{x}$ & & $\mathrm{x}$ & $\mathrm{x}$ & & & & & & & & \\
\hline [24] & $\mathrm{x}$ & $\mathrm{x}$ & & $\mathrm{x}$ & & $\mathrm{x}$ & $\mathrm{x}$ & & & & $\mathrm{x}$ & & & & \\
\hline$[25]$ & $\mathrm{x}$ & $\mathrm{x}$ & & & & $\mathrm{x}$ & $\mathrm{x}$ & & & $\mathrm{x}$ & & $\mathrm{x}$ & & & $\mathrm{x}$ \\
\hline [34] & $\mathrm{x}$ & $\mathrm{x}$ & & & & $\mathrm{x}$ & $\mathrm{x}$ & & & $\mathrm{x}$ & $\mathrm{x}$ & & & & \\
\hline$[50]$ & & & $\mathrm{x}$ & $\mathrm{x}$ & & $\mathrm{x}$ & & & $\mathrm{x}$ & & & $\mathrm{x}$ & $\mathrm{x}$ & $\mathrm{x}$ & $\mathrm{x}$ \\
\hline$[55]$ & & & & & & & $\mathrm{x}$ & $\mathrm{x}$ & $\mathrm{x}$ & & $\mathrm{x}$ & $\mathrm{x}$ & & $\mathrm{x}$ & $\mathrm{x}$ \\
\hline$[58]$ & $\mathrm{x}$ & $\mathrm{x}$ & $\mathrm{x}$ & & $\mathrm{x}$ & $\mathrm{x}$ & $\mathrm{x}$ & & $\mathrm{x}$ & & $\mathrm{x}$ & $\mathrm{x}$ & $\mathrm{x}$ & $\mathrm{x}$ & $\mathrm{x}$ \\
\hline [64] & $\mathrm{x}$ & $\mathrm{x}$ & & & & $\mathrm{x}$ & & & & $\mathrm{x}$ & & & & & \\
\hline [94] & $\mathrm{x}$ & & & $\mathrm{x}$ & $\mathrm{x}$ & $\mathrm{x}$ & $\mathrm{x}$ & $\mathrm{x}$ & $\mathrm{x}$ & & $\mathrm{x}$ & $\mathrm{x}$ & & $\mathrm{x}$ & $\mathrm{x}$ \\
\hline$[95]$ & $\mathrm{x}$ & $\mathrm{x}$ & & $\mathrm{x}$ & & $\mathrm{x}$ & $\mathrm{x}$ & & & & $\mathrm{x}$ & $\mathrm{x}$ & & & \\
\hline [96] & & & & $\mathrm{x}$ & & & $\mathrm{x}$ & $\mathrm{x}$ & & & & & & & \\
\hline$[97]$ & $\mathrm{x}$ & & & $\mathrm{x}$ & & & & & & & & $\mathrm{x}$ & & & \\
\hline [98] & $\mathrm{x}$ & $\mathrm{x}$ & & & & $\mathrm{x}$ & & & & $\mathrm{x}$ & & & & & \\
\hline [99] & & $\mathrm{x}$ & & & & $\mathrm{x}$ & $\mathrm{x}$ & & & & & & & & \\
\hline$[100]$ & $\mathrm{x}$ & & & & & $\mathrm{x}$ & & & & & & $\mathrm{x}$ & & & \\
\hline
\end{tabular}

Notes: $\mathrm{Av}=$ Atopobium vaginae $; \mathrm{Mob}=$ Mobiluncus $; \mathrm{Li}=$ Lactobacillus iners $; \mathrm{BVAB}=\mathrm{BV}$-associated bacteria (unidentified); Egg = Eggerthella; Meg = Megasphaera; Anaer = Anaerococcus (previously Peptostreptococcus); Pep = Peptoniphilus (previously Peptostreptococ).

Since the focus of this paper is directed at the microbes implicated in the aetiology and pathogenesis of $\mathrm{BV}$ and the role it may play in PTB, it will not elaborate on the details of these different diagnostic approaches, the strengths and weaknesses of which have previously been summarised [101].

\subsection{The Pathogenic Potential of BV-associated Anaerobes}

\subsubsection{Co-Aggregation and Attachment}

G. vaginalis has been reported to possess innate pathogenic potential [44] with two genomically different forms described: one being a commensal form slightly adhesive to epithelial cells, and the other, a pathogenic form found to be strongly adhesive to epithelial cells [33]. Because adherence is a vitally important virulence factor in the pathogenesis of $\mathrm{BV}$, the ability of $G$. vaginalis to adhere to vaginal epithelial cells may well pave the way for other microbes such as Peptoniphilus and A. vaginae 
to become established in the $\mathrm{BV}$-associated vaginal biofilm by co-aggregating with $G$. vaginalis in order to establish infection [44,102].

Other species such as Fusobacterium which also do not adhere well to vaginal epithelial cells [44], are able to facilitate co-aggregation between species such as Prevotella [103] and Bifidobacterium [104] in polymicrobial infections [105,106] by acting as a bridge between early and late colonisers in biofilm formation [107-109] and by supporting the growth of obligate anaerobes such as Porphyromonas, [110,111] in aerated and carbon dioxide depleted environments [110-112]. By adhering to other vaginal microbes [113], F. nucleatum is able to mask the surface components that are recognized by $\mathrm{H}_{2} \mathrm{O}_{2}$-producing lactobacilli and prevent detection by antagonistic microflora thus allowing for its integration into the developing vaginal microbial community associated with BV [114]. Bifidobacterium and Ureaplasma urealyticum have the ability to attach to erythrocytes and other eucaryotic cells, [115] and have therefore been reported to be independently associated with BV [9]. However, Bifidobacterium adolescentis, Bifidobacterium longum, Bifidobacterium breves, Bifidobacterium bifidum and Bifidobacterium catenulatum have been detected perianally only and not in the vagina [116], possibly due to weaker adherence mechanisms. While unable to co-aggregate directly with Actinomyces naeslundi or with Veillonella parvula, Bifidobacterium is known to attach to biofilms of $A$. naeslundii and $V$. parvula, in the presence of F. nucleatum [104] and may further contribute to the formation of the vaginal biofilm by producing amino acids which provide energy sources to other anaerobic bacteria such as Eggerthella lenta (previously Eubacterium lenta).

\subsubsection{Production of Volatile and Non-Volatile Fatty Acids}

Volatile fatty acids such as isovaleric or caproic acid are produced by species of Gram-positive cocci which induce alterations of the shape, composition and growth of eukaryotic cells [88] and may thus threaten pregnancy. Non-volatile fatty acids produced by vaginal anaerobes have been shown to inhibit chemotaxis and other PMN functions [88,117]. Other fatty acids produced by vaginal anaerobes include formic acid produced by Atopobium and Eggerthella, propionic acid produced by Propionibacterium, lactic acid produced by Bifidobacterium, Atopobium, Actinomyces, Collinsella aerofaciens (previously Eubacterium aerofaciens), Lactobacillus, Leptotrichia amnionii and Sneathia sanguinegens, butyric acid produced by Eubacterium, Slackia, Gram-positive cocci and acetic and succinic acids produced by anaerobic Gram-positive cocci, Mobiluncus, Prevotella, Atopobium, Bifidobacterium, Eggerthella, Actinomyces [118]. The production of malic acid and trimethylamine by Mobiluncus have been associated with vaginal irritation and the vaginal odour associated with BV, while Fusobacterium nucleatum is known to produce large amounts of ammonia, butyrate and hydrogen sulfide and thus, along with supporting the growth of other anaerobes, could also be contributing to the malodour associated with BV $[119,120]$.

The production of amines such as putrescine and cadaverine by anaerobic bacteria, resulting in an increase in $\mathrm{pH}$ and favouring the growth of other anaerobes implicated in BV is an example of bacterial synergy in the establishment of the vaginosis biofilm. 


\subsubsection{Enzyme and Lysine Production}

Mucin degrading enzymes produced by BV-associated bacteria deplete protective host mucous barriers [121] and facilitate adhesion to and colonisation of the underlying epithelium [122]. The production of collagenase and fibrinolysins by Prevotella bivia, Prevotella disiens and Leptorichia are reported to play a role in pathogenesis by degrading mucosal protective factors and detachment of vaginal epithelial cells [82] thereby contributing to the production of a vaginal discharge. Cytolysins are produced by L. iners [123] and G. vaginalis, causing cell death by activating the protein kinase pathway in human epithelial cells [44,124]. The production of IgA antibodies to vaginolysin (cytolysin produced by G. vaginalis) as a result of the mucosal immune response, further supports the role of vaginolysin in the pathogenesis of BV [125]. G. vaginalis also produces haemolysin, liberating nutrients for the feeding of other anaerobic bacteria. It has been suggested that U. urealyticum is the most virulent of the mollicutes [115], expressing haemolytic activity and secretion of enzymes such as elastase, IgA protease (reducing mucosal immunity), phospholipase C, [126], and urease which hydrolyses urea to cytotoxic ammonia. Vaginal sloughing is facilitated by the production of sialidase, prolidase [117,121] and putrescine by G. vaginalis, Mobilincus [122] Megasphaera, [62], Bactroides fragilis [122] and Prevotella bivia [82,117]. Proteolytic enzymes produced by many anaerobic species [44] damage oviduct mucosal surfaces, render the cilia unable to beat, and could possibly lead to infertility $[127,128]$.

\subsection{Bacterial Vaginosis and Its Threat to Pregnancy}

Vaginal mucosal cells and their glycoproteins are major components of the barrier which protects against infection. Cervical mucous protects the upper reproductive tract from microbial invasion. Among the antibacterial factors contained in mucous are lactoferrin, lysozyme and secretory $\operatorname{IgA}$. The amount and viscosity of mucosal flow is determined by the cervical mucins and thus reduced viscosity of the mucous allows for better infiltration of pathogens into the reproductive tract [122]. Evidence is mounting that ascending subclinical intrauterine infections in the gravid female may threaten pregnancy due to a host of different proinflammatory endogenous vaginal colonisers. By promoting colonisation of the upper reproductive tract, mucin degrading enzymes produced by BV-associated bacteria sometimes cause chorioamnionitis and other adverse pregnancy outcomes. Chemotactic cytokines are produced by several cell types, including injured tissues, and by acting on leucocytes, are involved in stimulating inflammatory mediators [26]. High vaginal bacterial loads may cause an increase in cytokine levels [129] particularly when G. vaginalis, F. nucleatum, staphylococci and streptococci are present [92]. G. vaginalis and A. vaginae frequently occur together in PTB [130,131], with A. vaginae also being detected in endometritis [132] a condition which may occur not only amongst non-pregnant women (in pelvic inflammatory disease), but could also occur after child birth or as a result of Casaerian delivery. Other BV-associated microbes associated with PTB include Mobiluncus, Mycoplasma [133] along with Bacteroides ureolyticus [134,135] and Fusobacterium [136].

L. amnionii and $S$. sanguinegens have been reported in pregnancy [137], and ascending infections involving the uterus, foetal membranes and fallopian tubes [138]. Being increasingly reported from 
obstetrics cases [85] they are associated with spontaneous abortion [138], septic abortion [139], PTB [86,140], peripartum fever [141] postpartum infection [138,141], and bacteraemia [142].

Although considered to be an indicator organism for BV [143,144], the role of Megasphaera in preterm birth remains speculative. M. hominis appears to increase the prevalence of U. urealyticum, C. trachomatis [145], BV and preterm delivery [146]. Together, M. hominis and U. urealyticum have been reported in cervicitis, pelvic inflammatory disease and obstetrical pathologies including premature delivery, premature rupture of membranes, chorio-amniotitis and pregnancy loss [9,145,147,148], while $U$. parvum has been associated with preterm birth and late spontaneous abortion [149]. The role of M. genitalium in both BV and pregnancy outcomes is less well defined since its presence appears to be dependent on other vaginal colonisers. The production of sialidase and other proteolytic enzymes capable of damaging host tissues and threatening pregnancy may implicate many of the anaerobic vaginal microflora in adverse pregnancy outcomes $[121,150]$.

\section{Summary and Conclusions}

Anaerobes dominate the microbiota of the human skin and mucous membranes and are thus commonly implicated in bacterial endogenous infections. Their identification and treatment are complicated by their inability to grow in routine culture thus resulting in their presence being missed or overlooked. The use of $16 \mathrm{~S}$ rRNA gene sequence-based analyses have frequently been used for the study of the vaginal microbiota, thus revealing the presence of many anaerobic species not previously detected by culture [57,58]. Our knowledge of the diversity of species associated with BV has thus increased as detection methods have improved [44,94].

The polymicrobial ecosystem of the vagina complicates the determination of the microbial aetiology of BV. Using culture-independent techniques, attempts have been made to differentiate the diversity of vaginal microbiota in BV-positive and BV-negative women [62,95,151], but there is no consensus regarding the microbial communities which bring about the change from a commensal microflora to an opportunistic microflora causing BV. Many of the studies reported, differ in patient selection, population groups, sampling techniques, diagnostic methods and laboratory detection methods with some studies (particularly molecular studies) selecting for the presence of specific species only and others (cultural studies) limited by the lack of nutrients required for the growth of fastidious species, thus leading to either over or under-representation of the prevalence of particular species.

The HIV-exposed foetus is at risk for PTB [152] thus the viricidal effect of $\mathrm{H}_{2} \mathrm{O}_{2}$-producing lactobacilli and the stimulation of growth factors by BV-associated bacteria have a direct impact on foetal and neonatal morbidity and mortality due to maternal HIV status [153]. However, conclusive evidence that treatment of BV reduces PTB is lacking thus BV is not considered by many as being a specific marker for PTB and focus is thus directed to the development of other biomarkers for adverse pregnancy outcomes. It has been suggested that aerobic vaginitis is a more serious threat for adverse pregnancy outcomes than BV [43] since it appears to be more damaging to the healthy vaginal environment than BV [81] and the increased cytokine production is thought to increase the risk of preterm delivery, chorioamnionitis and funisitis of the foetus [154].

Whether or not screening for BV, prevents PTB remains to be debated [155-157]. While some recommend that treatment of BV reduces the risk of PTB, others report an increase in 
PTB following treatment for BV [158]. Meanwhile, BVAB3 an anerobe prevalent in BV, was found to decrease the risk for PTB [133], a finding which may explain why come cases of BV may be involved in PTB and others not. Inconsistencies in clinical and laboratory detection methods used for the monitoring of treatment have a direct impact on success rates [76,83,155,159] thus complicating a comparison between the presence/absence of BV in PTB and full-term birth (FTB) [156]. Because different bacteria have different associations with Amsel diagnostic criteria, this may explain discrepancies often reported between Amsel criteria and microscopy [34]. Amsel clinical criteria provide no information on the vaginal microflora and while microscopy may provide information pertaining to the morphology of the vaginal bacteria, it provides no confirmation of the species present. Although strongly associated with BV, many bacteria have not been taxonomically identified [47,58], further adding to the complexity of the matter.

With some species associated with both health and disease, one needs to examine their pathogenic potential within specific microbial consortia, taking into account the inherent differences within and among different ethnic groups [160], sexual and hygiene practices, and host susceptibility [23]. It has been proposed that more information regarding the aetiology of BV may be attained by aggregating the microflora into higher taxonomic groups instead of considering the vaginal microflora at genus or species level [151] and that if the occurrence of BV is reduced and a healthy vaginal biofilm maintained, new cases of HIV infections may be considerably prevented [161] as will adverse pregnancy outcomes. Studies demonstrating the ability of specific bacteria to overcome immunity and alter the environment (be it synergistically or antagonistically) in favour of their survival, will greatly improve our understanding of the complexity of BV [39,47] and the microbial stimuli of inflammatory reactions which may initiate the cascade of events leading to preterm delivery. It is therefore imperative that a better understanding of the vaginal microbiome with a more explicit differentiation between health and disease microbiota be established, taking into account other risk factors which may modify their colonisation and pathogenic potential.

\section{Acknowledgments}

This material is based upon work partially supported financially by the National Research Foundation (NRF) of South Africa. Any opinion, findings, and conclusions or recommendations expressed in this material are those of the authors, and therefore, the NRF does not accept any liability in regards thereto.

\section{Author Contributions}

Charlene Africa wrote the paper and contributed to the literature search, Megan Stemmet and Janske Nel collated the data and contributed to the original draft of the manuscript.

\section{Conflicts of Interest}

The authors declare no conflict of interest. 


\section{References}

1. Di Vico, A.; Donati, L.; Labianca, A.; Quagliozzi, L.; Spagnuolo, T.; Bracaglia, M.; Nucci, M.; Caruso, A.; Paradisi, G. Role of vaginal infection in fetal and neonatal mortality. Minerva Ginecol. 2011, 63, 25-29.

2. Ishaque, S.; Yakoob, M.Y.; Imdad, A.; Goldenberg, R.L.; Eisele, T.P.; Bhutta, Z.A. Effectiveness of interventions to screen and manage infections during pregnancy on reducing stillbirths: A review. BMC Public Health 2011, 11, doi:10.1186/1471-2458-11-S3-S3.

3. Turovskiy, Y.; Sutyak Noll, K.; Chikindas, M.L. The aetiology of bacterial vaginosis. J. Appl. Microbiol. 2011, 110, 1105-1128.

4. Briery, C.M.; Chauhan, S.P.; Magann, E.F.; Cushman, J.L.; Morrison, J.C. Treatment of bacterial vaginosis does not reduce preterm birth among high-risk asymptomatic women in fetal fibronectin positive patients. J. Miss. State Med. Assoc. 2011, 52, 72-75.

5. Lamont, R.F.; Sobel, J.D.; Akins, R.A.; Hassan, S.S.; Chaiworapongsa, T.; Kusanovic, J.P.; Romero, R. The vaginal microbiome: New information about genital tract flora using molecular based techniques. BJOG 2011, 118, 533-549.

6. Culhane, J.F.; Desanto, D.; Goldenberg, R.L.; McCollum, K.F.; King, F.; Guaschino, S. Variation in Nugent score and leukocyte count in fluid collected from different vaginal sites. Obstet. Gynecol. 2005, 105, 120-123.

7. Menon, R.; Dunlop, A.L.; Kramer, M.R.; Fortunato, S.J.; Hogue, C.J. An overview of racial disparities in preterm birth rates: Caused by infection or inflammatory response? Acta Obstet. Gynecol. Scand. 2011, 90, 1325-1331.

8. Goldenberg, R.L.; Andrews, W.W.; Goepfert, A.R.; Faye-Petersen, O.; Cliver, S.P.; Carlo, W.A.; Hauth, J.C. The Alabama preterm birth study: Umbilical cord blood Ureaplasma urealyticum and Mycoplasma hominis cultures in very preterm newborn infants. Amer. J. Obstet. Gynecol. 2008, 198, 1-5.

9. Pepin, J.; Deslandes, S.; Giroux, G.; Sobela, F.; Khonde, N.; Diakite, S.; Demeule, S.; Labbe, A.C.; Carrier, N.; Frost, E. The complex vaginal flora of west African women with bacterial vaginosis. PLoS One 2011, 6, doi:10.1371/journal.pone.0025082.

10. Fredricks, D.N.; Fiedler, T.L.; Thomas, K.K.; Oakley, B.B.; Marrazzo, J.M. Targeted PCR for detection of vaginal bacteria associated with bacterial vaginosis. J. Clin. Microbiol. 2007, 45, 3270-3276.

11. Fethers, K.; Marks, C.; Mindel, A.; Estcourt, C.S. Sexually transmitted infections and risk behaviours in women who have sex with women. Sex. Transm. Infect. 2000, 76, 345-349.

12. Bradshaw, C.S.; Walker, S.M.; Vodstrcil, L.A.; Bilardi, J.E.; Law, M.; Hocking, J.S.; Fethers, K.A.; Fehler, G.; Petersen, S.; Tabrizi, S.N.; et al. The influence of behaviors and relationships on the vaginal microbiota of women and their female partners: The WOW health study. J. Infect. Dis. 2014, 209, 1562-1572.

13. Marrazzo, J.M.; Antonio, M.; Agnew, K.; Hillier, S.L. Distribution of genital Lactobacillus strains shared by female sex partners. J. Infect. Dis. 2009, 199, 680-683.

14. Tabrizi, S.N.; Fairley, C.K.; Bradshaw, C.S.; Garland, S.M. Prevalence of Gardnerella vaginalis and Atopobium vaginae in virginal women. Sex. Transm. Dis. 2006, 33, 663-665. 
15. Fethers, K.; Twin, J.; Fairley, C.K.; Fowkes, F.J.; Garland, S.M.; Fehler, G.; Morton, A.M.; Hocking, J.S.; Tabrizi, S.N.; Bradshaw, C.S. Bacterial Vaginosis (BV) candidate bacteria: Associations with $\mathrm{BV}$ and behavioural practices in sexually-experienced and inexperienced women. PLoS One 2012, 7 , doi:10.1371/journal.pone.0030633.

16. Shipitsyna, E.; Roos, A.; Datcu, R.; Hallen, A.; Fredlund, H.; Jensen, J.S.; Engstrand, L.; Unemo, M. Composition of the vaginal microbiota in women of reproductive age-Sensitive and specific molecular diagnosis of bacterial vaginosis is possible? PLoS One 2013, 8, doi:10.1371/journal.pone.0060670.

17. Schwebke, J.R.; Flynn, M.S.; Rivers, C.A. Prevalence of Gardnerella vaginalis among women with lactobacillus-predominant vaginal flora. Sex. Transm. Infect. 2014, 90, 61-63.

18. Biagi, E.; Vitali, B.; Pugliese, C.; Candela, M.; Donders, G.G.; Brigidi, P. Quantitative variations in the vaginal bacterial population associated with asymptomatic infections: A real-time polymerase chain reaction study. Eur. J. Clin. Microbiol. Infect. Dis. 2009, 28, 281-285.

19. Georgijevic, A.; Cjukic-Ivancevic, S.; Bujko, M. Bacterial vaginosis. Epidemiology and risk factors. Srpski Arhiv za Celokupno Lekarstvo 2000, 128, 29-33.

20. Borovkova, N.; Korrovits, P.; Ausmees, K.; Turk, S.; Joers, K.; Punab, M.; Mandar, R. Influence of sexual intercourse on genital tract microbiota in infertile couples. Anaerobe 2011, 17, 414-418.

21. Ngugi, B.M.; Hemmerling, A.; Bukusi, E.A.; Kikuvi, G.; Gikunju, J.; Shiboski, S.; Fredricks, D.N.; Cohen, C.R. Effects of bacterial vaginosis-associated bacteria and sexual intercourse on vaginal colonization with the probiotic Lactobacillus crispatus CTV-05. Sex. Transm. Dis. 2011, 38, 1020-1027.

22. Brotman, R.M.; Ravel, J.; Cone, R.A.; Zenilman, J.M. Rapid fluctuation of the vaginal microbiota measured by Gram stain analysis. Sex. Transm. Infect. 2010, 86, 297-302.

23. Marrazzo, J.M. Interpreting the epidemiology and natural history of bacterial vaginosis: Are we still confused? Anaerobe 2011, 17, 186-190.

24. Ling, Z.; Liu, X.; Chen, X.; Zhu, H.; Nelson, K.E.; Xia, Y.; Li, L.; Xiang, C. Diversity of cervicovaginal microbiota associated with female lower genital tract infections. Microb. Ecol. 2011, 61, 704-714.

25. Marrazzo, J.M.; Thomas, K.K.; Fiedler, T.L.; Ringwood, K.; Fredricks, D.N. Risks for acquisition of bacterial vaginosis among women who report sex with women: A cohort study. PLoS One 2010, 5, doi:10.1371/journal.pone.0011139.

26. Birley, H.; Duerden, B.; Hart, C.A.; Curless, E.; Hay, P.E.; Ison, C.A.; Renton, A.M.; Richens, J.; Wyatt, G.B. Sexually transmitted diseases: Microbiology and management. J. Med. Microbiol. 2002, 51, 793-807.

27. Schwebke, J.R.; Muzny, C.A.; Josey, W.E. Role of Gardnerella vaginalis in the pathogenesis of Bacterial Vaginosis: A Conceptual Model. J. Infect. Dis. 2014, doi:10.1093/infdis/jiu089.

28. Diao, Y.; Fang, X.; Xia, Q.; Chen, S.; Li, H.; Yang, Y.; Wang, Y.; Cui, J.; Sun, X.; Zhao, Z. Organism diversity between women with and without bacterial vaginosis as determined by polymerase chain reaction denaturing gradient gel electrophoresis and 16S rRNA gene sequence. J. Obstet. Gynaecol. Res. 2011, 37, 1438-1446. 
29. Klebanoff, M.A.; Nansel, T.R.; Brotman, R.M.; Zhang, J.; Yu, K.F.; Schwebke, J.R.; Andrews, W.W. Personal hygienic behaviors and bacterial vaginosis. Sex. Transm. Dis. 2010, 37, 94-99.

30. Schwiertz, A.; Taras, D.; Rusch, K.; Rusch, V. Throwing the dice for the diagnosis of vaginal complaints? Ann. Clin. Microbiol. Antimicrob. 2006, 5, doi:10.1186/1476-0711-5-4.

31. Forney, L.J.; Foster, J.A.; Ledger, W. The vaginal flora of healthy women is not always dominated by Lactobacillus species. J. Infect. Dis. 2006, 194, 1468-1469.

32. Trama, J.P.; Pascal, K.E.; Zimmerman, J.; Self, M.J.; Mordechai, E.; Adelson, M.E. Rapid detection of Atopobium vaginae and association with organisms implicated in bacterial vaginosis. Mol. Cell. Probes 2008, 22, 96-102.

33. Bohbot, J.M.; Lepargneur, J.P. Bacterial vaginosis in 2011: A lot of questions remain. Gynecol. Obstet. Fertil. 2012, 40, 31-36.

34. Srinivasan, S.; Hoffman, N.G.; Morgan, M.T.; Matsen, F.A.; Fiedler, T.L.; Hall, R.W.; Ross, F.J.; McCoy, C.O.; Bumgarner, R.; Marrazzo, J.M.; et al. Bacterial communities in women with bacterial vaginosis: High resolution phylogenetic analyses reveal relationships of microbiota to clinical criteria. PLoS One 2012, 7, doi:10.1371/journal.pone.0037818.

35. Vallor, A.C.; Antonio, M.A.; Hawes, S.E.; Hillier, S.L. Factors associated with acquisition of, or persistent colonization by, vaginal lactobacilli: Role of hydrogen peroxide production. J. Infect. Dis. 2001, 184, 1431-1436.

36. Polishko, T.N.; Sirokvasha, E.A.; Klokov, V.V.; Vinnikov, A.I. Comparative studying of anaerobic bacteria located in woman's reproductive ways in normal condition and dysbiosis. Likars 'ka Sprava/Ministerstvo Okhorony Zdorov'ia Ukrainy 2008, 3-4, 57-63.

37. Charonis, G.; Larsson, P.G. Use of $\mathrm{pH} /$ whiff test or Quickvue advanced $\mathrm{pH}$ and Amines test for the diagnosis of bacterial vaginosis and prevention of postabortion pelvic inflammatory disease. Acta Obstet. Gynecol. Scand. 2006, 85, 837-843.

38. Yoshimura, K.; Morotomi, N.; Fukuda, K.; Nakano, M.; Kashimura, M.; Hachisuga, T.; Taniguchi, H. Intravaginal microbial flora by the $16 \mathrm{~S}$ rRNA gene sequencing. Amer. J. Obstet. Gynecol. 2011, 205, 1-9.

39. Tamrakar, R.; Yamada, T.; Furuta, I.; Cho, K.; Morikawa, M.; Yamada, H.; Sakuragi, N.; Minakami, H. Association between Lactobacillus species and bacterial vaginosis-related bacteria, and bacterial vaginosis scores in pregnant Japanese women. BMC Infect. Dis. 2007, 7, doi:10.1186/1471-2334-7-128.

40. De Backer, E.; Verhelst, R.; Verstraelen, H.; Alqumber, M.A.; Burton, J.P.; Tagg, J.R.; Temmerman, M.; Vaneechoutte, M. Quantitative determination by real-time PCR of four vaginal Lactobacillus species, Gardnerella vaginalis and Atopobium vaginae indicates an inverse relationship between L. gasseri and L. iners. BMC Microbiol. 2007, 7, doi:10.1186/1471-2180-7-115.

41. Dumonceaux, T.J.; Schellenberg, J.; Goleski, V.; Hill, J.E.; Jaoko, W.; Kimani, J.; Money, D.; Ball, T.B.; Plummer, F.A.; Severini, A. Multiplex detection of bacteria associated with normal microbiota and with bacterial vaginosis in vaginal swabs by use of oligonucleotide-coupled fluorescent microspheres. J. Clin. Microbiol. 2009, 47, 4067-4077. 
42. Shopova, E.; Nikolov, A.; Dimitrov, A. Susceptibility to antibiotics of microorganisms related with recurrent bacterial vaginosis. Akusherstvo i Ginekologiia 2011, 50, 20-21.

43. Donders, G.G.; Vereecken, A.; Bosmans, E.; Dekeersmaecker, A.; Salembier, G.; Spitz, B. Definition of a type of abnormal vaginal flora that is distinct from bacterial vaginosis: Aerobic vaginitis. BJOG 2002, 109, 34-43.

44. Patterson, J.L.; Stull-Lane, A.; Girerd, P.H.; Jefferson, K.K. Analysis of adherence, biofilm formation and cytotoxicity suggests a greater virulence potential of Gardnerella vaginalis relative to other bacterial-vaginosis-associated anaerobes. Microbiology 2010, 156, 392-399.

45. Swidsinski, A.; Mendling, W.; Loening-Baucke, V.; Ladhoff, A.; Swidsinski, S.; Hale, L.P.; Lochs, H. Adherent biofilms in bacterial vaginosis. Obstetr. Gynecol. 2005, 106, 1013-1023.

46. Gilbert, N.M.; Lewis, W.G.; Lewis, A.L. Clinical features of bacterial vaginosis in a murine model of vaginal infection with Gardnerella vaginalis. PLoS One 2013, 8, doi: 10.1371/journal.pone.0059539.

47. Fredricks, D.N.; Fiedler, T.L.; Marrazzo, J.M. Molecular identification of bacteria associated with bacterial vaginosis. N. Engl. J. Med. 2005, 353, 1899-1911.

48. Burton, J.P.; Chilcott, C.N.; Al-Qumber, M.; Brooks, H.J.; Wilson, D.; Tagg, J.R.; Devenish, C. A preliminary survey of Atopobium vaginae in women attending the Dunedin gynaecology out-patients clinic: Is the contribution of the hard-to-culture microbiota overlooked in gynaecological disorders? Aust. N. Z. J. Obstet. Gynaecol. 2005, 45, 450-452.

49. Dols, J.A.; Smit, P.W.; Kort, R.; Reid, G.; Schuren, F.H.; Tempelman, H.; Bontekoe, T.R.; Korporaal, H.; Boon, M.E. Microarray-based identification of clinically relevant vaginal bacteria in relation to bacterial vaginosis. Amer. J. Obstet. Gynecol. 2011, 204, 1-7.

50. Srinivasan, S.; Fredricks, D.N. The human vaginal bacterial biota and bacterial vaginosis. Interdiscip. Perspect. Infect. Dis. 2008, 2008, doi:10.1155/2008/750479.

51. Danielsson, D.; Teigen, P.K.; Moi, H. The genital econiche: Focus on microbiota and bacterial vaginosis. Ann. N. Y. Acad. Sci. 2011, 1230, 48-58.

52. Togni, G.; Battini, V.; Bulgheroni, A.; Mailland, F.; Caserini, M.; Mendling, W. In vitro activity of nifuratel on vaginal bacteria: Could it be a good candidate for the treatment of bacterial vaginosis? Antimicrob. Agents Chemother. 2011, 55, 2490-2492.

53. Bradshaw, C.S.; Tabrizi, S.N.; Fairley, C.K.; Morton, A.N.; Rudland, E.; Garland, S.M. The association of Atopobium vaginae and Gardnerella vaginalis with bacterial vaginosis and recurrence after oral metronidazole therapy. J. Infect. Dis. 2006, 194, 828-836.

54. Burton, J.P.; Devillard, E.; Cadieux, P.A.; Hammond, J.A.; Reid, G. Detection of Atopobium vaginae in postmenopausal women by cultivation-independent methods warrants further investigation. J. Clin. Microbiol. 2004, 42, 1829-1831.

55. Zhou, X.; Brown, C.J.; Abdo, Z.; Davis, C.C.; Hansmann, M.A.; Joyce, P.; Foster, J.A.; Forney, L.J. Differences in the composition of vaginal microbial communities found in healthy Caucasian and black women. ISME J. 2007, 1, 121-133.

56. Ferris, M.J.; Masztal, A.; Aldridge, K.E.; Fortenberry, J.D.; Fidel, P.L., Jr.; Martin, D.H. Association of Atopobium vaginae, a recently described metronidazole resistant anaerobe, with bacterial vaginosis. BMC Infect. Dis. 2004, 4, doi:10.1186/1471-2334-4-5. 
57. Ferris, M.J.; Masztal, A.; Martin, D.H. Use of species-directed 16S rRNA gene PCR primers for detection of Atopobium vaginae in patients with bacterial vaginosis. J. Clin. Microbiol. 2004, 42, 5892-5894.

58. Fredricks, D.N.; Marrazzo, J.M. Molecular methodology in determining vaginal flora in health and disease: Its time has come. Curr. Infect. Dis. Rep. 2005, 7, 463-470.

59. Verhelst, R.; Verstraelen, H.; Claeys, G.; Verschraegen, G.; Delanghe, J.; van Simaey, L.; de Ganck, C.; Temmerman, M.; Vaneechoutte, M. Cloning of 16S rRNA genes amplified from normal and disturbed vaginal microflora suggests a strong association between Atopobium vaginae, Gardnerella vaginalis and bacterial vaginosis. BMC Microbiol. 2004, 4, doi:10.1186/1471-2180-4-16.

60. Verstraelen, H.; Verhelst, R.; Claeys, G.; Temmerman, M.; Vaneechoutte, M. Culture-independent analysis of vaginal microflora: The unrecognized association of Atopobium vaginae with bacterial vaginosis. Amer. J. Obstet. Gynecol. 2004, 191, 1130-1132.

61. Polatti, F. Bacterial vaginosis, Atopobium vaginae and nifuratel. Curr. Clin. Pharmacol. 2012, 7 , 36-40.

62. Marconi, C.; Donders, G.G.; Parada, C.M.; Giraldo, P.C.; da Silva, M.G. Do Atopobium vaginae, Megasphaera sp. and Leptotrichia sp. change the local innate immune response and sialidase activity in bacterial vaginosis? Sex. Transm. Infect. 2013, 89, 167-173.

63. Wang, X.; Li, X.; Zhao, C.; Hu, P.; Chen, H.; Liu, Z.; Liu, G.; Wang, Z. Correlation between composition of the bacterial community and concentration of volatile fatty acids in the rumen during the transition period and ketosis in dairy cows. Appl. Environ. Microbiol. 2012, 78, 2386-2392.

64. Hay, P. How important are the newly described bacteria in bacterial vaginosis? Sex. Transm. Infect. 2009, 85, 240-241.

65. Mitchell, C.; Moreira, C.; Fredricks, D.; Paul, K.; Caliendo, A.M.; Kurpewski, J.; Ingersoll, J.; $\mathrm{Cu}-$ Uvin, S. Detection of fastidious vaginal bacteria in women with HIV infection and bacterial vaginosis. Infect. Dis. Obstet. Gynecol. 2009, 2009, 1-6.

66. Marrazzo, J.M.; Fiedler, T.L.; Srinivasan, S.; Thomas, K.K.; Liu, C.; Ko, D.; Xie, H.; Saracino, M.; Fredricks, D.N. Extravaginal reservoirs of vaginal bacteria as risk factors for incident bacterial vaginosis. J. Infect. Dis. 2012, 205, 1580-1588.

67. Sha, B.E.; Zariffard, M.R.; Wang, Q.J.; Chen, H.Y.; Bremer, J.; Cohen, M.H.; Spear, G.T. Female genital-tract HIV load correlates inversely with Lactobacillus species but positively with bacterial vaginosis and Mycoplasma hominis. J. Infect. Dis. 2005, 191, 25-32.

68. Kapiga, S.H.; Sam, N.E.; Shao, J.F.; Renjifo, B.; Masenga, E.J.; Kiwelu, I.E.; Manongi, T.; Fawzi, W.; Essex, M. HIV-1 epidemic among female bar and hotel workers in northern Tanzania: Risk factors and opportunities for prevention. J. Acquir. Immune Defic. Syndr. 2002, 29, 409417.

69. Taha, T.E.; Hoover, D.R.; Dallabetta, G.A.; Kumwenda, N.I.; Mtimavalye, L.A.R.; Yang, L.P.; Liomba, G.N.; Broadhead, R.L.; Chiphangwi, J.D.; Miotti, P.G. Bacterial vaginosis and disturbances of vaginal flora: Association with increased acquisition of HIV. Aids 1998, 12, 1699-1706. 
70. Martin, H.L.; Richardson, B.A.; Nyange, P.M.; Lavreys, L.; Hillier, S.L.; Chohan, B.; Mandaliya, K.; Ndinya-Achola, J.O.; Bwayo, J.; Kreiss, J. Vaginal lactobacilli, microbial flora, and risk of human immunodeficiency virus Type 1 and sexually transmitted disease acquisition. J. Infect. Dis. 1999, 180, 1863-1868.

71. Mitchell, C.; Balkus, J.E.; Fredricks, D.; Liu, C.; McKernan-Mullin, J.; Frenkel, L.M.; Mwachari, C.; Luque, A.; Cohn, S.E.; Cohen, C.R.; et al. Interaction between lactobacilli, bacterial vaginosis-associated bacteria, and HIV Type 1 RNA and DNA Genital shedding in U.S. and Kenyan women. AIDS Res. Hum. Retrovir. 2013, 29, 13-19.

72. Donders, G.G. Treatment of sexually transmitted bacterial diseases in pregnant women. Drugs 2000, 59, 477-485.

73. Haggerty, C.L.; Hillier, S.L.; Bass, D.C.; Ness, R.B. Bacterial vaginosis and anaerobic bacteria are associated with endometritis. Clin. Infect. Dis. 2004, 39, 990-995.

74. Cassini, M.A.; Pilloni, A.; Condo, S.G.; Vitali, L.A.; Pasquantonio, G.; Cerroni, L. Periodontal bacteria in the genital tract: Are they related to adverse pregnancy outcome? Int. J. Immunopathol. Pharmacol. 2013, 26, 931-939.

75. Nawrot, R.; Kamieniarz, K.; Malinowska, M.; Jozefiak, A.; Kedzia, W.; Kwasniewska, A.; Kuzma, D.; Gozdzicka-Jozefiak, A. The prevalence of Leptotrichia amnionii in cervical swabs of HPV positive and negative women. Eur. J. Gynaecol. Oncol. 2010, 31, 425-428.

76. Lim, K.H.; Brooks, H.; McDougal, R.; Burton, J.; Devenish, C.; de Silva, T. Is there a correlation between bacterial vaginosis and preterm labour in women in the Otago region of New Zealand? Aust. N. Z. J. Obstet. Gynaecol. 2010, 50, 226-229.

77. Menard, J.P.; Mazouni, C.; Fenollar, F.; Raoult, D.; Boubli, L.; Bretelle, F. Diagnostic accuracy of quantitative real-time PCR assay vs. clinical and Gram stain identification of bacterial vaginosis. Eur. J. Clin. Microbiol. Infect. Dis. 2010, 29, 1547-1552.

78. Spiegel, C.A.; Amsel, R.; Holmes, K.K. Diagnosis of bacterial vaginosis by direct gram stain of vaginal fluid. J. Clin. Microbiol. 1983, 18, 170-177.

79. Nugent, R.P.; Krohn, M.A.; Hillier, S.L. Reliability of diagnosing bacterial vaginosis is improved by a standardized method of gram stain interpretation. J. Clin. Microbiol. 1991, 29, 297-301.

80. Hay, R.J. Infection, skin disease, and developing countries. Skinmed 2002, 1, 87-88.

81. Marconi, C.; Donders, G.G.; Bellen, G.; Brown, D.R.; Parada, C.M.; Silva, M.G. Sialidase activity in aerobic vaginitis is equal to levels during bacterial vaginosis. Eur. J. Obstet. Gynecol. Reprod. Biol. 2013, 167, 205-209.

82. Al-Mushrif, S.; Eley, A.; Jones, B.M. Inhibition of chemotaxis by organic acids from anaerobes may prevent a purulent response in bacterial vaginosis. J. Med. Microbiol. 2000, 49, 1023-1030.

83. Nygren, P.; Fu, R.; Freeman, M.; Bougatsos, C.; Klebanoff, M.; Guise, J.M. Evidence on the benefits and harms of screening and treating pregnant women who are asymptornatic for bacterial vaginosis: An update review for the U.S. preventive services task force. Ann. Intern. Med. 2008, $148,220-233$.

84. Klebanoff, M.A.; Guise, J.M.; Carey, J.C. Treatment recommendations for bacterial vaginosis in pregnant women. Clin. Infect. Dis. 2003, 36, 1630-1631. 
85. Shukla, S.K.; Meier, P.R.; Mitchell, P.D.; Frank, D.N.; Reed, K.D. Leptotrichia amnionii sp. nov., a novel bacterium isolated from the amniotic fluid of a woman after intrauterine fetal demise. J. Clin. Microbiol. 2002, 40, 3346-3349.

86. Huang, M.; Wang, J.H. Gram stain as a relapse predictor of bacterial vaginosis after metronidazole treatment. J. Microbiol. Immunol. Infect. 2005, 38, 137-140.

87. Hillier, S.L. Diagnostic microbiology of bacterial vaginosis. Amer. J. Obstet. Gynecol. 1993, 169, 455-459.

88. Fiorilli, A.; Molteni, B.; Milani, M. Successful treatment of bacterial vaginosis with a policarbophil-carbopol acidic vaginal gel: Results from a randomised double-blind, placebo-controlled trial. Eur. J. Obstet. Gynecol. Reprod. Biol. 2005, 120, 202-205.

89. Stanek, R.; Gain, R.E.; Glover, D.D.; Larsen, B. High performance ion exclusion chromatographic characterization of the vaginal organic acids in women with bacterial vaginosis. BMC Chromatogr. 1992, 6, 231-235.

90. Fredricks, D.N.; Fiedler, T.L.; Thomas, K.K.; Mitchell, C.M.; Marrazzo, J.M. Changes in vaginal bacterial concentrations with intravaginal metronidazole therapy for bacterial vaginosis as assessed by quantitative PCR. J. Clin. Microbiol. 2009, 47, 721-726.

91. Chan, R.C.; Mercer, J. First Australian description of Eggerthella lenta bacteraemia identified by 16S rRNA gene sequencing. Pathology 2008, 40, 409-410.

92. Nikolaitchouk, N.; Andersch, B.; Falsen, E.; Strombeck, L.; Mattsby-Baltzer, I. The lower genital tract microbiota in relation to cytokine-, SLPI- and endotoxin levels: Application of checkerboard DNA-DNA hybridization (CDH). APMIS 2008, 116, 263-277.

93. Ison, C.A.; Hay, P.E. Validation of a simplified grading of Gram stained vaginal smears for use in genitourinary medicine clinics. Sex. Transm. Infect. 2002, 78, 413-415.

94. Thies, F.L.; Konig, W.; Konig, B. Rapid characterization of the normal and disturbed vaginal microbiota by application of $16 \mathrm{~S}$ rRNA gene terminal RFLP fingerprinting. J. Med. Microbiol. 2007, 56, 755-761.

95. Ling, Z.; Kong, J.; Liu, F.; Zhu, H.; Chen, X.; Wang, Y.; Li, L.; Nelson, K.E.; Xia, Y.; Xiang, C. Molecular analysis of the diversity of vaginal microbiota associated with bacterial vaginosis. BMC Genomics 2010, 11, doi:10.1186/1471-2164-11-488.

96. Boggess, K.A.; Trevett, T.N.; Madianos, P.N.; Rabe, L.; Hillier, S.L.; Beck, J.; Offenbacher, S. Use of DNA hybridization to detect vaginal pathogens associated with bacterial vaginosis among asymptomatic pregnant women. Amer. J. Obstet. Gynecol. 2005, 193, 752-756.

97. Zhang, Y.; Yang, Y.; Shi, W.Y.; Cai, J.T.; Yang, L. Study of the bacterial community structure of microbiota in bacterial vaginosis using amplified ribosomal DNA restriction analysis. J. Southern Med. Univ. 2008, 28, 1626-1629.

98. Haggerty, C.L.; Totten, P.A.; Ferris, M.; Martin, D.H.; Hoferka, S.; Astete, S.G.; Ondondo, R.; Norori, J.; Ness, R.B. Clinical characteristics of bacterial vaginosis among women testing positive for fastidious bacteria. Sex. Transm. Infect. 2009, 85, 242-248.

99. Mitchell, C.M.; Hitti, J.E.; Agnew, K.J.; Fredricks, D.N. Comparison of oral and vaginal metronidazole for treatment of bacterial vaginosis in pregnancy: Impact on fastidious bacteria. BMC Infect. Dis. 2009, 9, doi:10.1186/1471-2334-9-89. 
100. Marconi, C.; Cruciani, F.; Vitali, B.; Donders, G.G. Correlation of atopobium vaginae amount with bacterial vaginosis markers. J. Lower Genital Tract Dis. 2012, 16, 127-132.

101. Africa, C.W. Efficacy of methods used for the diagnosis of bacterial vaginosis. Expert Opin. Med. Diagn. 2013, 7, 189-200.

102. Braga, P.C.; Dal Sasso, M.; Culici, M.; Spallino, A. Inhibitory activity of thymol on native and mature Gardnerella vaginalis biofilms: In vitro study. Arzneimittel-Forschung 2010, 60, 675-681.

103. Okuda, T.; Kokubu, E.; Kawana, T.; Saito, A.; Okuda, K.; Ishihara, K. Synergy in biofilm formation between Fusobacterium nucleatum and Prevotella species. Anaerobe 2012, 18, 110-116.

104. Nagaoka, S.; Hojo, K.; Murata, S.; Mori, T.; Ohshima, T.; Maeda, N. Interactions between salivary Bifidobacterium adolescentis and other oral bacteria: In vitro coaggregation and coadhesion assays. FEMS Microbiol. Lett. 2008, 281, 183-189.

105. Kaplan, C.W.; Lux, R.; Haake, S.K.; Shi, W. The Fusobacterium nucleatum outer membrane protein $\mathrm{RadD}$ is an arginine-inhibitable adhesin required for inter-species adherence and the structured architecture of multispecies biofilm. Mol. Microbiol. 2009, 71, 35-47.

106. Kawamura, C.; Nakamura, T.; Watanabe, K.; Kaimori, M. Retrospective analysis of Fusobacterium associated infections; experience at Aomori Prefectural hospital with 108 cases from 1995 to 1999. Kansenshogaku Zasshi. 2002, 76, 23-31.

107. Kolenbrander, P.E. Multispecies communities: Interspecies interactions influence growth on saliva as sole nutritional source. Int. J. Oral Sci. 2011, 3, 49-54.

108. Periasamy, S.; Kolenbrander, P.E. Central role of the early colonizer Veillonella sp. in establishing multispecies biofilm communities with initial, middle, and late colonizers of enamel. J. Bacteriol. 2010, 192, 2965-2972.

109. Kolenbrander, P.E.; Andersen, R.N.; Blehert, D.S.; Egland, P.G.; Foster, J.S.; Palmer, R.J., Jr. Communication among oral bacteria. Microbiol. Mol. Biol. Rev. 2002, 66, 486-505.

110. Metzger, Z.; Blasbalg, J.; Dotan, M.; Tsesis, I.; Weiss, E.I. Characterization of coaggregation of Fusobacterium nucleatum PK1594 with six Porphyromonas gingivalis strains. J. Endod. 2009, $35,50-54$.

111. Kuboniwa, M.; Hendrickson, E.L.; Xia, Q.; Wang, T.; Xie, H.; Hackett, M.; Lamont, R.J. Proteomics of Porphyromonas gingivalis within a model oral microbial community. BMC Microbiol. 2009, 9, doi:10.1186/1471-2180-9-98.

112. Diaz, P.I.; Zilm, P.S.; Rogers, A.H. Fusobacterium nucleatum supports the growth of Porphyromonas gingivalis in oxygenated and carbon-dioxide-depleted environments. Microbiology 2002, 148, 467-472.

113. Zilm, P.S.; Rogers, A.H. Co-adhesion and biofilm formation by Fusobacterium nucleatum in response to growth $\mathrm{pH}$. Anaerobe 2007, 13, 146-152.

114. He, X.; Hu, W.; Kaplan, C.W.; Guo, L.; Shi, W.; Lux, R. Adherence to streptococci facilitates Fusobacterium nucleatum integration into an oral microbial community. Microb. Ecol. 2012, 63, $532-542$.

115. Larsen, B.; Hwang, J. Mycoplasma, Ureaplasma, and adverse pregnancy outcomes: A fresh look. Infect. Dis. Obstet. Gynecol. 2010, 2010, 1-7. 
116. Swidsinski, A.; Dorffel, Y.; Loening-Baucke, V.; Mendling, W.; Schilling, J.; Patterson, J.L.; Verstraelen, H. Dissimilarity in the occurrence of Bifidobacteriaceae in vaginal and perianal microbiota in women with bacterial vaginosis. Anaerobe 2010, 16, 478-482.

117. Cauci, S.; Culhane, J.F.; Di Santolo, M.; McCollum, K. Among pregnant women with bacterial vaginosis, the hydrolytic enzymes sialidase and prolidase are positively associated with interleukin-1beta. Amer. J. Obstet. Gynecol. 2008, 198, 1-7.

118. Romanik, M.; Friedek, D.; Wojciechowska-Wieja, A.; Martirosian, G. Atopobium vaginae: Characterization and association with pathogenesis of bacterial vaginosis. Ginekol. Pol. 2006, 77, 398-403.

119. Fukamachi, H.; Nakano, Y.; Yoshimura, M.; Koga, T. Cloning and characterization of the L-cysteine desulfhydrase gene of Fusobacterium nucleatum. FEMS Microbiol. Lett. 2002, 215, 75-80.

120. Kapatral, V.; Anderson, I.; Ivanova, N.; Reznik, G.; Los, T.; Lykidis, A.; Bhattacharyya, A.; Bartman, A.; Gardner, W.; Grechkin, G.; et al. Genome sequence and analysis of the oral bacterium Fusobacterium nucleatum strain ATCC 25586. J. Bacteriol. 2002, 184, 2005-2018.

121. Lewis, W.G.; Robinson, L.S.; Gilbert, N.M.; Perry, J.C.; Lewis, A.L. Degradation, foraging, and depletion of mucus sialoglycans by the vagina-adapted Actinobacterium Gardnerella vaginalis. J. Biol. Chem. 2013, 288, 12067-12079.

122. Wiggins, R.; Hicks, S.J.; Soothill, P.W.; Millar, M.R.; Corfield, A.P. Mucinases and sialidases: Their role in the pathogenesis of sexually transmitted infections in the female genital tract. Sex. Transm. Infect. 2001, 77, 402-408.

123. Macklaim, J.M.; Cohen, C.R.; Donders, G.; Gloor, G.B.; Hill, J.E.; Parham, G.P.; Ravel, J.; Spear, G.; van de Wijgert, J.; Reid, G. Exploring a road map to counter misconceptions about the cervicovaginal microbiome and disease. Reprod. Sci. 2012, 19, 1154-1162.

124. Gelber, S.E.; Aguilar, J.L.; Lewis, K.L.; Ratner, A.J. Functional and phylogenetic characterization of Vaginolysin, the human-specific cytolysin from Gardnerella vaginalis. J. Bacteriol. 2008, 190, 3896-3903.

125. Cauci, S.; Hitti, J.; Noonan, C.; Agnew, K.; Quadrifoglio, F.; Hillier, S.L.; Eschenbach, D.A. Vaginal hydrolytic enzymes, immunoglobulin A against Gardnerella vaginalis toxin, and risk of early preterm birth among women in preterm labor with bacterial vaginosis or intermediate flora. Amer. J. Obstet. Gynecol. 2002, 187, 877-881.

126. Udayalaxmi, J.; Bhat, G.K.; Kotigadde, S. Biotypes and virulence factors of Gardnerella vaginalis isolated from cases of bacterial vaginosis. Ind. J. Med. Microbiol. 2011, 29, 165-168.

127. Taylor-Robinson, D.; Boustouller, Y.L. Damage to oviduct organ cultures by Gardnerella vaginalis. Int. J. Exp. Pathol. 2011, 92, 260-265.

128. Van Oostrum, N.; de Sutter, P.; Meys, J.; Verstraelen, H. Risks associated with bacterial vaginosis in infertility patients: A systematic review and meta-analysis. Hum. Reprod. 2013, 28, 1809-1815.

129. Hedges, S.R.; Barrientes, F.; Desmond, R.A.; Schwebke, J.R. Local and systemic cytokine levels in relation to changes in vaginal flora. J. Infect. Dis. 2006, 193, 556-562.

130. Menard, J.P.; Mazouni, C.; Salem-Cherif, I.; Fenollar, F.; Raoult, D.; Boubli, L.; Gamerre, M.; Bretelle, F. High vaginal concentrations of Atopobium vaginae and Gardnerella vaginalis in women undergoing preterm labor. Obstet. Gynecol. 2010, 115, 134-140. 
131. Menard, J.P.; Bretelle, F. How can the treatment of bacterial vaginosis be improved to reduce the risk of preterm delivery? Womens Health 2012, 8, 491-493.

132. Yamagishi, Y.; Mikamo, H.; Tanaka, K.; Watanabe, K. A case of uterine endometritis caused by Atopobium vaginae. J. Infect. Chemother. 2011, 17, 119-121.

133. Foxman, B.; Wen, A.; Srinivasan, U.; Goldberg, D.; Marrs, C.F.; Owen, J.; Wing, D.A.; Misra, D. Mycoplasma, bacterial vaginosis-associated bacteria BVAB3, race, and risk of preterm birth in a high-risk cohort. Amer. J. Obstet. Gynecol. 2014, 210, 1-7.

134. Kalinka, J.; Laudanski, T.; Hanke, W.; Krzeminski, Z.; Wasiela, M. The evaluation of prevalence and the impact of pathological microflora of the lower genital tract among women at early pregnancy on the risk of preterm delivery. Med. Dosw. Mikrobiol. 2003, 55, 277-284.

135. Boggess, K.A.; Moss, K.; Murtha, A.; Offenbacher, S.; Beck, J.D. Antepartum vaginal bleeding, fetal exposure to oral pathogens, and risk for preterm birth at $<35$ weeks of gestation. Amer. J. Obstet. Gynecol. 2006, 194, 954-960.

136. Hitti, J.; Hillier, S.L.; Agnew, K.J.; Krohn, M.A.; Reisner, D.P.; Eschenbach, D.A. Vaginal indicators of amniotic fluid infection in preterm labor. Obstet. Gynecol. 2001, 97, 211-219.

137. Joesoef, M.; Schmid, G. Bacterial vaginosis. Clin. Evid. 2002, 1400-1408.

138. Thilesen, C.M.; Nicolaidis, M.; Lokebo, J.E.; Falsen, E.; Jorde, A.T.; Muller, F. Leptotrichia amnionii, an emerging pathogen of the female urogenital tract. J. Clin. Microbiol. 2007, 45, 2344-2347.

139. Koumans, E.H.; Lane, S.D.; Aubry, R.; Demott, K.; Webster, N.; Levandowski, B.A.; Berman, S.; Markowitz, L.E. Evaluation of Syracuse Healthy Start's program for abnormal flora management to reduce preterm birth among pregnant women. Matern. Child Health J. 2011, 15, 1020-1028.

140. Berghella, V.; Klebanoff, M.; McPherson, C.; Carey, J.C.; Hauth, J.C.; Ernest, J.M.; Heine, R.P.; Wapner, R.J.; Trout, W.; Moawad, A.; et al. Sexual intercourse association with asymptomatic bacterial vaginosis and Trichomonas vaginalis treatment in relationship to preterm birth. Amer. J. Obstet. Gynecol. 2002, 187, 1277-1282.

141. Koumans, E.H.; Markowitz, L.E.; Hogan, V. Indications for therapy and treatment recommendations for bacterial vaginosis in nonpregnant and pregnant women: A synthesis of data. Clin. Infect. Dis. 2002, 35, S152-S172.

142. De Martino, S.J.; Mahoudeau, I.; Brettes, J.P.; Piemont, Y.; Monteil, H.; Jaulhac, B. Peripartum bacteremias due to Leptotrichia amnionii and Sneathia sanguinegens, rare causes of fever during and after delivery. J. Clin. Microbiol. 2004, 42, 5940-5943.

143. Cartwright, C.P.; Lembke, B.D.; Ramachandran, K.; Body, B.A.; Nye, M.B.; Rivers, C.A.; Schwebke, J.R. Development and validation of a semiquantitative, multitarget PCR assay for diagnosis of bacterial vaginosis. J. Clin. Microbiol. 2012, 50, 2321-2329.

144. Marrazzo, J.M.; Thomas, K.K.; Fiedler, T.L.; Ringwood, K.; Fredricks, D.N. Relationship of specific vaginal bacteria and bacterial vaginosis treatment failure in women who have sex with women. Ann. Intern. Med. 2008, 149, 20-28.

145. Odendaal, H.J.; Popov, I.; Schoeman, J.; Grove, D. Preterm labour-Is Mycoplasma hominis involved? S. Afr. Med. J. 2002, 92, 235-237.

146. Capoccia, R.; Greub, G.; Baud, D. Ureaplasma urealyticum, Mycoplasma hominis and adverse pregnancy outcomes. Curr. Opin. Infect. Dis. 2013, 26, 231-240. 
147. Donders, G.G.; van Bulck, B.; Caudron, J.; Londers, L.; Vereecken, A.; Spitz, B. Relationship of bacterial vaginosis and mycoplasmas to the risk of spontaneous abortion. Amer. J. Obstet. Gynecol. 2000, 183, 431-437.

148. Pararas, M.V.; Skevaki, C.L.; Kafetzis, D.A. Preterm birth due to maternal infection: Causative pathogens and modes of prevention. Eur. J. Clin. Microbiol. Infect. Dis. 2006, 25, $562-569$.

149. Kataoka, S.; Yamada, T.; Chou, K.; Nishida, R.; Morikawa, M.; Minami, M.; Yamada, H.; Sakuragi, N.; Minakami, H. Association between preterm birth and vaginal colonization by mycoplasmas in early pregnancy. J. Clin. Microbiol. 2006, 44, 51-55.

150. Santiago, G.L.; Deschaght, P.; El Aila, N.; Kiama, T.N.; Verstraelen, H.; Jefferson, K.K.; Temmerman, M.; Vaneechoutte, M. Gardnerella vaginalis comprises three distinct genotypes of which only two produce sialidase. Amer. J. Obstet. Gynecol. 2011, 204, 1-7.

151. Oakley, B.B.; Fiedler, T.L.; Marrazzo, J.M.; Fredricks, D.N. Diversity of human vaginal bacterial communities and associations with clinically defined bacterial vaginosis. Appl. Environ. Microbiol. 2008, 74, 4898-4909.

152. Slyker, J.A.; Patterson, J.; Ambler, G.; Richardson, B.A.; Maleche-Obimbo, E.; Bosire, R.; Mbori-Ngacha, D.; Farquhar, C.; John-Stewart, G. Correlates and outcomes of preterm birth, low birth weight, and small for gestational age in HIV-exposed uninfected infants. BMC Pregnancy Childbirth 2014, 14, doi:10.1186/1471-2393-14-7.

153. Chuachoowong, R.; Shaffer, N.; Siriwasin, W.; Chaisilwattana, P.; Young, N.L.; Mock, P.A.; Chearskul, S.; Waranawat, N.; Chaowanachan, T.; Karon, J.; et al. Short-course antenatal zidovudine reduces both cervicovaginal human immunodeficiency virus type 1 RNA levels and risk of perinatal transmission. Bangkok Collaborative Perinatal HIV Transmission Study Group. J. Infect. Dis. 2000, 181, 99-106.

154. Donders, G.; Bellen, G.; Rezeberga, D. Aerobic vaginitis in pregnancy. BJOG 2011, 118, $1163-1170$.

155. Guise, J.M.; Mahon, S.M.; Aickin, M.; Helfand, M.; Peipert, J.F.; Westhoff, C. Screening for bacterial vaginosis in pregnancy. Amer. J. Prev. Med. 2001, 20, 62-72.

156. Manns-James, L. Bacterial vaginosis and preterm birth. J. Midwifery Womens Health 2011, 56, $575-583$.

157. Brocklehurst, P.; Gordon, A.; Heatley, E.; Milan, S.J. Antibiotics for treating bacterial vaginosis in pregnancy. Cochrane Database Syst. Rev. 2013, 1, doi:10.1002/14651858.CD000262.pub4.

158. Ganu, R.S.; Ma, J.; Aagaard, K.M. The role of microbial communities in parturition: Is there evidence of association with preterm birth and perinatal morbidity and mortality? Amer. J. Perinatol. 2013, 30, 613-624.

159. Libman, M.D.; Kramer, M.; Platt, R. Comparison of Gram and Kopeloff stains in the diagnosis of bacterial vaginosis in pregnancy. Diagn. Microbiol. Infect. Dis. 2006, 54, 197-201.

160. Ravel, J.; Gajer, P.; Abdo, Z.; Schneider, G.M.; Koenig, S.S.; McCulle, S.L.; Karlebach, S.; Gorle, R.; Russell, J.; Tacket, C.O.; et al. Vaginal microbiome of reproductive-age women. Proc. Natl. Acad. Sci. USA 2011, 108, S4680-S4687. 
161. Myer, L.; Denny, L.; Telerant, R.; Souza, M.; Wright, T.C., Jr.; Kuhn, L. Bacterial vaginosis and susceptibility to HIV infection in South African women: A nested case-control study. J. Infect. Dis. 2005, 192, 1372-1380.

(C) 2014 by the authors; licensee MDPI, Basel, Switzerland. This article is an open access article distributed under the terms and conditions of the Creative Commons Attribution license (http://creativecommons.org/licenses/by/3.0/). 